\title{
Outcaste or Internal Exile? Ambiguous Bodies in the Making of Modern Japan
}

\author{
Timothy Amos, Australian National University
}

\section{Introduction}

\begin{abstract}
Exile is one of the saddest fates. In pre-modern times banishment was a particularly dreadful punishment since it not only meant years of aimless wandering away from family and familiar places, but also meant being a sort of permanent outcast, someone who never felt at home, and was always at odds with the environment, inconsolable about the past, bitter about the present and the future. There has always been an association between the idea of exile and the terrors of being a leper, a social and moral untouchable (Said 1994, 47).
\end{abstract}

The association between exile and outcast that Edward Said eludes to here evokes powerful images. For Said, exile, particularly in its premodern form of banishment, was tragic. This was the case not only because it physically dislodged people from cherished landscapes brimming with familiar bodies, but because it tore the subject away from a home, an environment, and indeed a history, transforming the displaced being into both a physical and emotional outcast. Clearly, the exile in this passage takes on a somewhat orthodox appearance, as Marie-Paule Ha has noted, a notion resting upon the 'assumption of a convergence of the self and the native place' (Ha 2001, para.1). But it is this familiar exilic form that will largely inform the ensuing discussions of the subject below.

Certainly, the linkage between dislocation that results in a state of uprootedness and the notion of outcast is not a construction restricted to writers on exile. Albert Memmi, for example, when referring to those people living in 'painful and constant ambiguity'national groups that were 'neither colonizers nor colonized' within the colonial apparatus - also makes reference to the term 'outcast' (Memmi 1965, 13-5). Moreover, Dhan Gopal Mukerji, in the mid 1920s, introduced the period of his life in the United 
States in terms of being an 'outcast' (Mukerji 1925). Other individuals and groups too have appropriated the term outcast, including sufferers of mental disabilities and HIVinfected communities, to refer to their conditions.

Interestingly, the conditions experienced by those actually labelled and treated as outcastes in many ways closely resemble common descriptions of exile. Sukhadeo Thorat, for example, describes the situation for Dalits in a rural Indian village: 'From the age when you learn to walk and talk, the limits are delineated: residential, physical and social isolation combined with day-to-day humiliation. All rural Dalit children face one form of humiliation or the other. At school, there is hardly any interpersonal relationship between the Dalit student and the teacher, and the feeling of isolation is heightened' (Anand 2003, para. 8). Babasaheb Ambedkar, writing in an earlier period, clearly agreed:

It is not a case of social separation, a mere stoppage of social intercourse for a temporary period. It is a case of territorial segregation and of a cordon sanitaire putting the impure people inside a barbed wire into a sort of a cage. Every Hindu village has a ghetto. The Hindus live in the village and the Untouchables in the ghetto' (Ambedkar 1948, 22).

There would appear then to be a considerable link between notions of exile and outcaste. In the following sections of this paper, we will firstly analyse the linkages between the 'exile', 'outcast', and outcaste, highlighting both points of interchangeableness and departure for these concepts as they relate specifically to a certain historical context in Japan. Second, after a brief background discussion, we will examine the state/condition of being an outcaste in the Bakumatsu or late Tokugawa period, and consider how close this situation was to a state of exile. Third, we will examine a specific example of the act of re-inclusion of outcastes into their local community created by the 1871 Emancipation Edict that led to the creation of the 'former outcaste' or 'new citizen', and analyse to what extent this embodies the process of returning from exile. Lastly, the paper will conclude with a brief discussion of the extent to which a crossover between the terms outcaste and exile may be applicable in the Japanese context, as well as the positive aspects of attempting such a conceptual reconfiguration. 


\section{Outcast through space}

The applicability of the term outcast by displaced peoples to refer to their various states of exclusion is readily apparent. The intense pain incurred as a result of a dislocation from places of intimacy and landscapes of profound attachment is captured by many authors, but perhaps none more simplistically and eloquently then by Mahmud Darwish who writes of exile: 'we travel like other people, but we return to nowhere' (quoted in Bowman 1994, 138). One visible thread of this complex tapestry of exclusion and selfidentity that can be readily teased from Darwish's discourse is the close relationship between the notion of exile and the ideas of space and belonging. Nira Yuval-Davis further helps unravel these latter concepts for us:

\footnotetext{
Belonging is where the sociology of emotions interfaces with the sociology of power, where identification and participation collude, or are at least aspired to or yearned for. Like other hegemonic constructions, belonging tends to become 'naturalized' and thus invisible in hegemonic formations. It is only when one's safe and stable connection to the collectivity, the homeland, the state, becomes threatened, that it becomes articulated and reflexive rather than just performative (Yuval-Davis 2003, para. 13).
}

If we attempt to unravel this strand even more, putting the idea into everyday language, we can probably pronounce that one has a profound attachment to a place because complex values, meanings and associations are ascribed to it; and the tendency is for the feeling of belonging associated with that particular place to often be politically manufactured, leaving the holder of these emotions hypersensitive to any form of interference, especially intrusions that demand a separation of the physical body from a material place. And, it is at the very point where these meanings and associations are threatened that 'protest about the meaning of place may erupt' (Buttimer 1980, 167).

But while acknowledging the role of the political hand in the assembly of notions of belonging, Suh Kwungsik's warning not to 'trivialise the notion of exile' still firmly resounds. After all, the severing of a connection with 'the collectivity' is often done in a calculated way and with a cold blade; as Suh again cautions, 'the nation has the power to determine the citizenship and the identity of the people living within its borders', including the ability, for example, to 'exile from the mother tongue' (Suh 2004, para. 28). 
Tessa Morris-Suzuki has clearly illustrated how the Japanese policies of forced assimilation of the Ainu and Okinawans into the modern Japanese nation state during the $19^{\text {th }}$ and $20^{\text {th }}$ centuries rent apart two distinctive cultures (Morris-Suzuki 1996; 2000).

The majority of these men and women were rendered internal exiles-outcasts in their own land. Therefore, it appears vital to remember that while pain resulting from any form of exile does arise out of a sense of belonging to an imagined community, it also often results from a violent act that forces relocation into very real spaces of hardship and oppression.

Essentially, in the case of the exile, the meanings and associations ascribed to place are not simply threatened, but the threats are actually acted upon—one's 'safe and stable connection to the collectivity' is savagely incised. It is in this isolated state that our exile exists, remaining connected to 'the collectivity' with only the slightest of threadsperhaps more often than not an imagined thread kept taut by emotion or spirit rather than in any real or concrete sense. Possibly, it is better to say that the exile is rendered incapable of belonging through the act of exile, and those who cannot belong are of course ultimately known as and indeed in time regularly come to regard themselves as outcasts.

\section{Outcast through time}

An exile is not merely cast out of space, but also out of time. As Said intimates, the exile is removed from history. For the exile, as well as for all others who lose access to a common history, 'places are lost-destroyed, vacated, barred-but then there is some new place, and it is not the first, never can be the first [italics mine]' (Butler 2003, 468). In other words, not only the advent of the 'new place', but also the passage of time itself inserts a wedge between the displaced and their object of longing. We see that the movement of time drives the exile further and further away from what is familiar, creating an insurmountable distance consisting of linear moments, something that signals the irretrievability of the past. 
Clearly, time for the exile is intimately intertwined with notions of space, so that separating the two may even seem futile, but it may be worthwhile to consider some of the ways it closely contributes to the exilic condition. Undoubtedly, as it purveys to our study below, the 'moment' that lay somewhere between premodernity and modernity - a moment particularly transparent in the Japanese experience-was another important example where 'traditional' meanings and associations attributed to place came into sharp conflict with more 'modern' ones. Those in the engine (ering) room of Japanese modernity had a clear agenda that appeared at odds with idealist notions of community that often existed before, particularly in rural areas. This onset of modernity is a common tale and well described by Anne Buttimer who writes: 'In the bustling enthusiasm of early industrialisation it was far more important to expand horizons of access to markets and clientele than to seriously try to make the city [or village] a home' (Buttimer 1980, 167).

Indeed, the premodern Japanese subject living on the fault line between Japanese 'tradition' and 'modernity' can also be seen as a kind of outcast of time. 'Tradition' too, was often imagined (predominantly by Japanese males) in the mid-19 ${ }^{\text {th }}$ century as a kind of place, where modernity existed as either a threat or a promise-or a strange concoction of both. And with the sudden inability to ascribe (and therefore to derive) a meaning and association from that place, we see that both identity as well as identity crisis came to be derived from a sense of a loss of place (Chow, Doak \& Fu 2001, 6-7). For the Japanese who saw modernity as a threat, to be an outcast meant to be left behind - to be cast out by modernity, to be cast out by time. ${ }^{1}$

Perhaps it is an inherent part of modernity that it tends to persuade all and sundry of their inherent ambiguity. As John Lie writes, 'we moderns are...all exiles; exile is a condition endemic to modernity' (Lei 2001,353). Yet too much reflection on the alleged homogeneity caused by modern angst can only too easily mask the multiplicities of

\footnotetext{
${ }^{1}$ It is useful here to remember Harry Harootunian's caution about how we view the 'time-lag' contemporaneously, being careful about partaking in the 'scandal of imagining modernities that are not quite modern', and of situating 'societies like Japan in a historical trajectory derived from another's development' (Harootunian 2000, p. xvi).
} 
displacement that occur across class, gender, and ethnic boundaries. There are differing degrees of permanence in this state of time-related exile, as well as differing degrees of profit that may be derived from selling such an ideology of uniform anxiety.

There would also be one more important aspect related to time here, and that is the notion of future time, heavily embedded into the notions of exile and outcaste. The exile, it is assumed in the above passage by Said, has once known a home, an environment, and a history, and it is the distressing act of physical dislocation and the necessity to deal with the emotions and stigmas attached to such a violent act that generate significant portions of this tragic narrative. In order to emphasize the potent sting of such a fate, Said employs the imagery of the leper or the untouchable; people the reader intuits are permanently confined to such a catastrophic providence. In contrast to this, the outcaste (rather than outcast) is never really acquainted with a home, an environment, or a history apart from the one of total displacement they have experienced. While 'exile is inexorably tied to homeland and to the possibility of return,' the outcaste knows no home, no other state, other than exclusion (Naficy 1999, 3). There can be no hope of return.

It is interesting to note that very rarely do members of outcast communities, whether they are writing on exile, colonialism, modernity, or any other state of exclusion, use the term outcaste to refer to their plight, or indeed envisage themselves as one. Most opt for the term outcast - a seemingly innocent, yet undoubtedly deeply relevant distinction. For outcaste, purely by the inclusion of the last vowel, semantically mutates, creating a sense of permanent exclusion, a nuance that is not necessarily fully contained in the word outcast. But this hope generated through fiddling with concepts deeply touched by time is false. As John Lie states, 'In temporal displacement, the search for home (the remembered past) is inextricable from the condition of exile (the lived, and everchanging, present). The very passage of time makes this impossible' (Lei 2001, 353). We discover that there is very little difference in reality after all between the notions of exile, 
outcast, or outcaste in the passage of time - the decision to frame it in such a way is merely one of politics. ${ }^{2}$

\section{Exile and the outcaste in time/space}

As we are made aware in the above discussions, there is an inseparable relationship between issues of displacement and movements of time and space. Inherent in discussions of displacement are not just issues of space and place (i.e. being a space apart from somewhere), but also relationships of time (the vital questions of how long such a displacement will last and the way we frame the particular movements of time). In short, the ideas of permanence and temporality are crucial in any investigation of exiles, outcasts, or outcastes - as important as notions of displacement or exclusion.

But while the time relationship between exile and outcaste may be largely different (and politically charged), there would appear to be many points of convergence between the state of being an exile and the state of being an outcaste with regards to space. The condition of exile quoted from Said in the beginning strongly resonates with the experiences of not only the Indian outcaste mentioned above, but also the premodern

\footnotetext{
${ }^{2}$ This statement, of course, is at odds with the conclusions of many local historians in Japan who have argued for much of the post-war period (following the mainstream Japanese Marxian interpretation first penned by Inoue Kiyoshi) for the existence of an objective 'outcaste status' that is believed to exist within class. In the imaginings of such scholars, the Buraku problem is formed at the point that notions of outcaste-ness and pollution become attached to concrete occupational divisions within class, and these status distinctions are preserved and reinforced throughout Japanese history, most notably in the Tokugawa period when additional restraints placed on occupational mobility and residence served to cement outcaste groups into an outcaste status within a feudal system of class relations. Subsequently, the failure to remove these status distinctions in the modern era is believed to have led to the 'preservation' of the 'Buraku problem' that is essentially 'feudal'. For the initial introduction of this argument see Inoue 1998 [1950]. Certainly through the scholarship of Kuroda Toshio (1975) and Minegishi Kentarō (1996) interesting variations and diversions have resulted from Inoue's original thesis, but for the most part, as Tsukada Takashi (2000, p. 229) argues, Inoue's original thesis has been dominant in premodern outcaste studies in Japan. Clearly, this paper seeks to explore other interpretative possibilities concerning the 'Buraku problem,' particularly following the lead of scholars such as Imanishi Hajime (2000) and Hatanaka Toshiyuki (1999) who are exploring the possibilities of the 'modern origins' of the Buraku and the relationship between modernity, the modern nation-state, and the outcaste. Thinking through the relationship between outcastes and exiles (i.e., examining issues of marginalisation, boundary creation, and belonging) follows in this new tradition in attempting to reimagine the Buraku problem outside of the established framework of class and status.
} 
Japanese outcaste (senmin / hisabetsumin) that may be detected through archival records. The junction also appears to occur on a multiplicity of levels.

First, on a literal level, we may find concrete evidences of exile defined narrowly as a kind of banishment in the Japanese records on outcastes. If we sift through $19^{\text {th }}$ century outcaste historical records and the sparse histories written about them, we may certainly find examples of more orthodox cases of exile, where outcastes were expelled to the Japanese frontiers to assist in Empire-building (McCormack 2002a).

Or second, we may move to the still concrete yet slightly more figurative zone of exile whereby the outcaste was dislocated from communities while still remaining at 'home'. As Japanese historians from Inoue Kiyoshi to Wakita Osamu have frequently stressed, one important and central determinant of the premodern Japanese outcaste status is restrictions placed upon their residence (Inoue 1950; Wakita 1987). Some historians like Seshimo Hirohito have discussed this exclusion in concrete terms by referring to how outcaste settlements were predominantly found on riverbanks, outer-city limits, between hills and on slopes, and in riverbeds - areas that other members of the population did not wish to occupy (Seshimo 1982, 265). On the other hand, other scholars have focused on the everyday aspects of spatial exclusion, such as the lost ability to share meals or room space with other human beings (Minegishi 1996). This enforced separation from a physical space and the obvious emotional trauma and stigma attached to such an act of separation suggests that there is a great overlap between the premodern Japanese outcaste and exile spoken about by Said.

Arguably, drawing on the observations of Japanese scholars, we can best understand the relationship between exile and outcaste through an even closer examination of our notions of space and place. Orthodox notions of exile, similar to Said's above, often place the exilic subject outside the borders of the established collective-commonly the nation or state. There are however, forms of bodily expulsion such as internal exile, whereby the subject does not necessarily exist in exile outside these boundaries - as in the relatively recent case of the Iranian academic Hashem Aghajari 'exiled to three remote Iranian 
cities for eight years'(Associated Press Newswires 7 Nov. 2002). It is in this dimension of internal exile that we may detect multiple similarities between exiles and outcastes - in that these individuals/groups occupy disparate 'spaces' within the same 'place.,

\section{The state of the outcaste in pre-1871 Japan}

Rather than leave our observations here, it is perhaps expedient to further pursue a precise moment when outcaste notions of space and place were challenged, and the space for the connection between these people and the collectivity was made. The 'moment' entrusted below to the historical microscope is related to the very interesting problem of $19^{\text {th }}$ century Japanese 'outcaste emancipation' where large numbers of men, women, and children were, remarkably enough, legally unshackled from their status as outcastes through the 1871 Emancipation Edict (Mibun kaihörei), and permitted (if not ordered) to participate in the making of modern Japan as 'new ordinary citizens' (shinheimin). This act of emancipation promised the outcaste a life more ordinary, and in a sense, it was a historical moment akin to a return from exile-where the severed connection between body and place was re-established, and all space allegedly became equally accessible to all members of the Japanese nation-state. 'Home,' for the late premodern outcaste, was of course the same physical place as before, but it meant the ability to share spaces that were previously off limits, spaces both real and imagined that had perhaps always appeared as warm and alluring_-yet unreachable. Rather than drawing on images of one's own past attachment to these places, many outcastes drew on nostalgic images of the historically privileged positions of farmers located within their communities in premodern times, and held this as their ideal. Homeland was for the outcaste peaceful, productive, and largely unremarkable: the outcastes intended to exist as themselves in someone else's space within the same place, and the Emancipation Edict was initially seen as that one political act that would make this vision a reality.

\footnotetext{
${ }^{3}$ My thanks goes to Tessa Morris-Suzuki for drawing my attention to the idea of disparate notions of place/space between exile and outcaste in these examples. It is also interesting to note that the notions of 'internal exile' and outcaste tend to resist the movements of time. They are decidedly premodern or antimodern in nature and are associated with backwardness.
} 
But these hopeful visions grew out of an optimism that interpreted the Edict in isolation from the myriad of other laws and policies designed by Meiji oligarchs to lay the foundations for a modern and competitive Japanese nation-state. In the decade that followed the Meiji Restoration of 1868, Japan embraced innumerable upheavals that dramatically altered the majority of its social, political, and economic institutions and traditions. In rural areas, the most significant shifts occurred in relation to the systems of land ownership and taxation. Within the Tokugawa system, land was subject to rights of hereditary, and in this sense, the introduction of 'modern' private land ownership in the early years of Meiji was clearly not an indigestible foreign concept to landed peasants. For the most part under Tokugawa law, land did belong to the peasant. But at the same time, authorities were also able to confiscate individual property and banish people from their own property for reasons such as failure to pay taxes, criminal activity, or even sometimes arbitrarily - for example, during adjudication of a legal dispute between two peasants. Therefore, the economic livelihood of individual peasants in the premodern era was heavily dependent upon their ability to obediently produce for the warrior class. Moreover, peasants also operated within a village community that was the official unit by which taxes (paid both in cash and kind) were collected and presented to the authorities. Individual land cultivation fell under the larger category of communal responsibility for tax burdens imposed from above, meaning that it was clearly in community interests to devise methods for preventing the economic collapse of individual peasants. In the face of the harsh realities confronted by peasants in the rural Tokugawa village, numerous systems such as early modern forms of financial cooperatives (tanomoshikō) were established in order to help protect individuals from bankruptcy.

With the sale of farm land expressly forbidden in Tokugawa society, struggling farmers weighed down under the heavy yoke of taxation (sometimes reaching rates of 50 percent of total crop yield) often slipped through the creative safety nets established in village communities, and were left with little choice but to mortgage their land to wealthier village members. Such peasants, after mortgaging their land, were frequently unable to generate enough capital to repay the initial sum borrowed against their land, and property therefore became increasingly concentrated in the hands of a rich farming class $(g \bar{o} n \bar{o})$ by 
the turn of the $19^{\text {th }}$ century. Peasants who did not take flight were often required to become tenant farmers working for these wealthy rural households, and it is probably no coincidence that the period from the late $18^{\text {th }}$ century to the Meiji Restoration saw unprecedented levels of peasant uprisings (Walthall 1986, xi). It was optimistically hoped by some of these individuals that any changes in the land and taxation system instituted under the new Meiji government might facilitate an increased share of the land for the poorer rural denizens.

The land and tax policies of the new Meiji government, however, worked contrary to these expectations. Under the land tax reforms commenced in 1871, the Meiji government set out to create a tax base founded on the principle of private land ownership and individual fiscal responsibility that maintained the same impressive levels of taxation achieved under the Tokugawa regime. Those landowners who presented their old deeds and titles received a 'modern' certificate of proprietorship that simply traced new lines over existing patterns of land ownership. Moreover, estimating the value of land (and therefore the amount of land tax an individual had to pay) was a highly subjective calculation that was often predictably computed to line rather than deplete government coffers, and the perceived unfairness of the new system regularly incurred the wrath of both small and large landowners during the course of the $1870 \mathrm{~s}$. The land and tax laws introduced in the early Meiji period served to further impoverish the tenant stratum, and create and entrench an elaborate landlord system in modern Japan that was to last until the postwar Occupation reforms. Subsequently, the visions of peasant-hood conjured up in the minds of underprivileged, rural 'former outcastes' discussed above were fanciful and ephemeral, as the realities of quotidian existence in the modern era became increasingly evident in the early years of the 1870 s.

\section{Emancipation edict and the end of the impure exile}

The 'outcaste order' was legally abolished in 1871 through the Emancipation Edict that was expected to enable all members of society to become ordinary Japanese citizens (heimin). The Emancipation Edict though, was not a piece of legislation simply plucked 
out of thin air, as is often thought. In 1868, we see that a move towards legal emancipation was already in motion with the official elevation of the Danzaemon as well as 70 of his closest aids to people of 'ordinary status'. The document that sealed the Danzaemon's elevation in status gives several official reasons for the promotion, such as the fact that he assisted when a fire burnt down one of the main gaols in Edo, and that he had gathered together an army of outcastes to assist the Shogunate in an attack on Chōshū fief (Hirota 1990, 69). It is interesting to note here that the elevation in status was also accompanied by a change in name to Dannaiki, and Dannaiki was quick to spread news of his new name and status change throughout all the towns and villages (pp.70-71). Perhaps we may read into this act of renaming a sense of the need for new labels of identification in order to occupy the 'new spaces' of a modernising Japan.

Just as the Danzaemon's elevation in status was posited in terms of what the outcaste had done for the late feudal state, so too were subsequent requests for elevation of status by other eta groups predating the Emancipation Edict often based upon arguments of what the outcaste communities could provide for the Shogunate. The eta of Watanabe Village in Sesshū province, for example, listed as one of their main arguments for emancipation in 1870 the fact that they had been ready and prepared to fight foreigners encroaching on Japanese soil with halberds if need be (when there was initial talk of 'expelling the barbarian') - a loyalist intention that was abruptly interrupted when a peace treaty was signed with the foreigners. This new development had clearly demoralized the eta community and they expressed great disconcertment that they should continue to be regarded as polluted because they were meat-eaters even though meat-eating foreigners were on peaceful terms with the rest of the population. The Watanabe Village community requested the authorities that the two Chinese characters for eta meaning 'much pollution' be officially struck from their social and legal status designation (Hirota 1990, pp. 71-2).

We gain the impression from these examples of a very clear association in both government circles and in outcaste communities between a restoration of social status and meritorious service to the state. One way or another, outcastes such as the eta that were 
apparently completely resolute in their 'outcaste-ness' through genetics only 50 years earlier, theoretically and in practice were actually able to earn their way back from their impure exile. These men and women were suddenly permitted to occupy the same spaces as other 'Japanese' because they had been seen to contribute something to the construction of the nation.

Some eta though, by 1870, had taken matters of emancipation into their own hands. Many attempted to terminate their expulsion as outcastes of their own volition, and endeavoured to seize the uneasily defined spaces of normality. An official inspector employed to describe popular conditions in the countryside to the central government reported in 1870 that there were rumours that farmers and merchants running restaurants, bathhouses, and barbershops were being forced out of business because eta customers were entering their stores. The inspector further records though that in Okayama, the bathhouse owners were able to find ways to counter this exercising of agency. By calling themselves Innertown Baths (chōnai furō), and giving out wooden passes to their customers, they could refuse entry to those customers without them, presumably in this way able to maintain the regimes of exclusion set in place against the eta (Hirota 1990, pp.81-2).

In August 1871, through the remonstrations of mostly well-placed politicians of quite elite backgrounds, the Emancipation Edict was formally promulgated. When the news of the dissemination of the Edict did eventually reach both outcaste and 'ordinary' communities, predictably enough, there were mixed reactions. Some prefectural governments took the promulgation of the Edict as an opportunity to lecture both 'ordinary citizens' and 'new ordinary citizens' on the importance of the Edict. The Ehime Prefectural Government, for example, advised those that had difficulty accepting the Edict to understand that the eta were a product of Japan before it was civilised, that eta too were most undoubtedly the Emperor's subjects, and that they were the exactly the same as 'ordinary people' in terms of their nature and intelligence. At the same time though, they advised the eta to work hard at their farming, to live cleanly, to tidy up after 
themselves, to wash meat thoroughly, to be careful of body odour, and to avoid all actions that the 'ordinary citizens' considered to be unclean (Hirota 1990, 79).

Several months after the promulgation of the Edict in January 1872, more concrete and disturbing reactions began to surface. The eta of Nakazui village in Okayama Prefecture, for example, used the law as a spring pad to recoil from the impure spaces they had been forced to occupy during the Tokugawa period. They requested permission from the prefectural government to resign from all duties related to criminal investigation, banishing beggars, and disposal of dead animal carcasses. To this, the local citizens predictably complained that they were being inconvenienced by such a petition, and subsequently retaliated by refusing the outcastes access to communal land set aside for cropping, vegetable production, and natural fuels such as firewood. Moreover, storeowners from neighbouring villages, perhaps not even directly related to the conflict, refused to sell products to members of the eta community. The problem quickly reached an impasse when a 'former eta' villager, turned away from a local tavern, was joined by local eta villagers in a large-scale demonstration. According to the document, the angry non-eta villagers then allegedly banded together, summoned together three 'former eta' village heads, and over a period of time brutally killed them all (Hirota 1990, pp.83-4).

What is genuinely interesting here is that the Emancipation Edict, while opening up spaces that were previously apparently 'off limits' to the outcaste community, gave no forewarning about the mass exodus into the spaces of others that would ensue, and local communities like the one above reacted in the strongest possible terms. We detect that in many ways the outcastes had already become at home in the alleged spaces of exclusion in their communities - they were obviously able to access communal farm land, and enter stores and taverns before the promulgation of the Edict. The official approval for the occupation of such spaces served to agitate many who themselves increasingly felt displaced - probably mostly by the onset of Japanese modernity.

There can be little doubt that many of the motivations for the promulgation of the Emancipation Edict were directly related to the desire by oligarchs, politicians, and 
bureaucrats to establish a more efficient national space. The eta and hinin were clearly a troublesome eyesore in the process of nation-building that was being diligently inspected by Western powers. Nakano Itsuki, a prominent politician at the time, argued for the emancipation of the outcastes because the land of these people had traditionally been measured differently, something that he believed should be made uniform in the 'Empire' (kōkoku) (quoted in Takeki Osatake 1999, pp. 64-5). Kumagaya Teizō and Inazu Itsuki, also politicians involved in the debate on outcaste emancipation, argued that there were no foreseeable problems in their view in getting members of outcaste communities to assist in performing national labour services. Others too, commented on the need to include the outcastes in a national household registry (pp. 66-7). What we witness here is a push for the homogenisation of national space and an acute desire transformed into policy to evenly measure and efficiently manage that space. There would be no more room on a national level for the existence of the impure and dangerous spaces of the premodern outcaste.

The outcaste was an internal exile before the promulgation of the Emancipation Edict, and the Edict symbolised an attempt to restore the exile to the literal as well as figurative land from which they were displaced. For the elites this was about building an empire around a well-measured and tightly controlled nation-state. But we may note that it was a largely unpopular act for many members of the community that were meant to embrace 'the return' of the outcaste into the same spaces within the same location. The Edict, precisely because it was promulgated from above, and disregardful of the grassroots attempts by many eta to be liberated in earlier years, failed to make a meaningful connection with local communities who were historically the agents who had to manage and enforce the previous policies of exclusion. The 'non-outcaste' communities had traditionally been asked to derive much of their identity from their privileged position that rested on their successful ability to exclude others including the outcaste, and a legislative act of emancipation threatened their own secure spaces in a rapidly transforming society. 
Historically, the outcastes, although theoretically residents in the same place, were squeezed into spaces of exile in regional communities: spaces that were slowly built into local domains of fear and hate. Unsurprisingly, the large exodus of eta back from the outcaste wilderness into the promised land of the modern Japanese nation was an idea that could only be accomplished if all eyes remained firmly fixed on the progress and success of the nation. But in local communities, quite predictably, many still thought in terms of local space and local privilege, and therefore, the main battles that former outcastes had to fight in the initial months after the promulgation of the Edict were not necessarily with governments, but rather with local communities that refused to share space with these former outcaste bodies.

\section{The treatment of the newly returned - the case of outcastes in Saitama}

The Emancipation Edict was promulgated by the Council of State (Daijōkan) on August 281871 , and a copy of that edict remains with some of the other documentation concerning a certain Village A found in the Saitama Prefectural Archives. ${ }^{4}$ The copy found in The Documents of the House of $M$, reads like any other copy of the Emancipation Edict - the abolition of the terms eta and hinin; the addition of all these people into the 'family register' (koseki) system; the statement that these people named eta and hinin were to be the same as average citizens (heimin) with regards to social status and occupation; and the order to report to the authorities if there was a custom in the village of waiving land taxes for the outcastes. Where the documents from Village A differ to some of the other copies of the Emancipation Edict in other villages is that because it is written up by the local village head as an oath of obedience (ukegaki), the outcaste headman of Village A made a memo at the end of the document promising to report to the authorities if there was a custom in the village of waiving land taxes ( $M K M$, \#4). This memo clearly indicates that the last of the four parts of the edict - the one

\footnotetext{
${ }^{4}$ The documents that figure in the following sections labelled M-kemonjo [The Documents of the House of M] were gathered from the Saitama Prefectural Archives during fieldwork in 2003. These documents are 'designated documents' (shitei bunsho) and are restricted because of their sensitive nature and because they contain the surnames of persons that may still live in the community. Subsequently, names of documents, places, and people have all been replaced with pseudonyms to ensure the protection of the privacy of the descendants of these individuals. Hereafter MKM.
} 
related to taxation practices - was considered (at least by this local leader) as one of the most important in the Edict. It may be deduced from this that an important reason for the promulgation of the Edict by the new Meiji government was related to the need to find ways to fund the many parts of the state projects of modernisation and civilisation that they were to undertake, and an important way of doing this was by creating a new and complete base of taxation.

It is certainly the case that the general interpretation of this Edict is highly negative; in fact, many scholars interpret this document as a legalised robbery of industries traditionally monopolized by the eta and hinin. Kobayashi Shigeru, one of the leading Japanese scholars on the topic, elaborates his stance on the Edict as follows:

\begin{abstract}
It is true that legally, through the 'Edict of Emancipation of Social Status,' the Buraku became like everyone else in both status and occupation. However, that was all this measure did: administrative measures befitting an 'Edict of Emancipation' were not undertaken in the slightest. Thus, the Buraku were left in their poverty that was caused by discrimination and based on social status that had existed since the Edo period; there were no guarantees of employment to reinforce this 'emancipation' (Kobayashi 1988, 101).
\end{abstract}

Kobayashi's perspective is certainly a very important one, a perspective that distinguishes between the ideology and practice of the Meiji government. But as the term emancipation suggests, there was also the very real aspect of liberation - a promise of, and in some cases, the reality of an alleviation of previously rigid structures and status delineations. Kobayashi also reproduces in his book a photostat of the 1871 Kinrai nendaiki, an Osaka Municipal Government document, where we find former outcastes running around the city with 'great joy' (Kobayashi 1998, ii). There is little doubt that the promise of liberation from centuries of oppression as members of outcaste communities was initially a cause for great joy for many of those that would come to be known as "new ordinary citizens.'

In the years leading up to the promulgation of the Edict, we see a great uncertainty amongst outcastes about their new position in the emerging modern Japanese nationstate. In Lower Wana Village, located in approximately the same region as Village A, for 
example, we find in 1869 in the months after the Meiji Restoration an official document laying out the rules after the Restoration. In this document, the eta villagers are reminded that they are still responsible to the Danzaemon and that they must still perform the duties that they performed for the Danzaemon, even though the name of their new employer was now Tokyo City (Tokyo-fu). The problem with the hinin is pronounced in this document too. With new rules concerning jurisdiction, the problem arose of when a hinin should become involved in official business. Temporary official duties were to be undertaken but where normal people (shirōto) or warriors were involved, the hinin were to leave it up to Tokyo City. There was also the problem of the fact that hinin were allowed to wear swords and to carry arms, something that changes in the early years of Meiji. In a time of rapid change, the Danzaemon recognized that many of the hinin that were going to perform official duties must be armed but would not be familiar with the 'rules' (hōsoku) of outcaste business. In addition, the problem of earning a living by begging on auspicious occasions and during Buddhist funeral rights became problematic, and suddenly there arose a need for hinin to have licences in order to peddle certain goods on the street. ${ }^{5}$

Village A, the village that is central to the discussion below, was a small village with a population that averaged fewer than 100 in the latter half of the Tokugawa period. The figures though are not clear but one temple register dated in the 1840s has the eta population at approximately 70 , with a hinin population of 5(MKM, \#6). This was not necessarily a small population for an outcaste village in eastern Japan, but certainly much smaller than the village of Minami Ōji in Osaka, written about by Dana Morris and Thomas C. Smith, which had a population of a little under 2000 by the second quarter of the $19^{\text {th }}$ century, and considerably smaller than Lower Wana Village in the same period (Morris and Smith 1985, 233).

In the month following the promulgation of the Emancipation Edict, on September 16 1871, we find a record from Village A of what was going on in its community at the time

\footnotetext{
${ }^{5}$ Suzukikemonjo [Documents of the House of Suzuki], No. 16, Saitama Prefectural Archives. Hereafter SKM.
} 
of the decree. The outcaste heads of Village A addressed a document to the non-eta village officials divided into three sections, reporting on three different goings on in the community at that time $(M K M, \# 11)$. Firstly, the eta village head of Village A writes that on September 15, the village officials of neighbouring Village S gathered the villagers together and explained the contents of the Edict of Emancipation to the villagers as follows:

1. Social status, as well as the office of eta village head, would be abolished

2. The eta would be allowed to bear surnames and use the title of farmer on official documentation

3. All duties, without fail, would be the same for everyone

4. The eta would be allowed to wear standard Japanese dress such as haori and hakama

5. The eta would be allowed to wear what they liked

6. The eta would be permitted to enter a house of a village official regardless of whether or not they were on public or private business

The second section of the document related to the concurrent activities of Village $\mathrm{H}$ in the same county. The eta heads of Village A explain in the document that the farmers of Village $\mathrm{H}$, after a town meeting, called the outcaste village elders of the village and all the eta villagers together, informing them that there had been an Edict of Emancipation, and that they now 'were the same as everybody else.' They were informed that in future, when they were dealing with 'important people,' they could give and receive documents without fear of reprisal. The author of the document (Village A eta headman) then writes that some 'important people' of a place nearby in the township celebrated with drinks with 10 'nobleman,' and then after that, they were all invited to the home of Y, a 'former outcaste leader now farmer' where they were poured drinks and gave Y four containers of sake in exchange for four trays of hors d'oeuvre's.

The third section of the document deals with Village K, which is not in the same county but the same province as Village A. In that village, the actual special police commissioner of eastern Japan (Kantō torishimariyaku) appeared in person and informed 
the former farming village officials as well as the former eta village head $\mathrm{T}$ that they were now the leaders of the village. The special police commissioner of eastern Japan also informed the men of the village that that were all now 'equally ordinary men.' Then the outcaste leader $\mathrm{T}$ received the official documentation from the commissioner, being told he may now have a surname and the title of farmer, and that he must perform his duties as group leader the same as the other three men.

We can see from this document that Kobayashi's statement that 'administrative measures befitting an "Edict of Emancipation" were not undertaken in the slightest' is somewhat problematic, for we have a clear example that it was not only possible, but in some places the practice for outcaste leaders to simply change clothes into their new modern Japanese village leadership garb. In this sense, we might even say that it was easier for some outcaste leaders with higher profiles to find their way into the new spaces of a supposedly egalitarian modern Japan. This was possible because these leaders were actually not receiving permission through the Edict to occupy new spaces - they were in fact already part of the establishment, impure exiles only in name but not in actuality, warmly embraced into part of the new administration because they were clearly already part of the old.

This was almost certainly not the case for the subclasses of outcastes resident in the village, and certainly not true for all outcaste village leaders. We can also see that while each village struggled to interpret the conditions of the Emancipation Edict in their own way, a common interpretation was that the former outcastes were now to be considered farmers. To outcastes living in rural communities in eastern Japan, the notion of 'average citizen' or heimin literally meant being allowed to be a 'farmer', as well as changes in other more practical concerns such as the ability to wear the clothes of one's choice, the ability to enter into someone's house at will, and the ability to be able to use one's own last name. Philosophically, the Emancipation Edict for the outcaste meant, it was hoped, being able to have a 'stable life' (anjī), an expression that finds its way into the concluding petitions of this document as well as others of the time like it. 
Any euphoria created by the Emancipation Edict and the celebrations that ensued probably did not last long. On September 23, 1871 we find the following appeal sent from the former outcaste village elder in Village $\mathrm{H}$ (a village located near Village A) to the local village officials. The 'former outcaste' village elder persisted in signing his name on the document in the language of the pre-Emancipation Edict era, suggesting perhaps a tentativeness to lay claims to the freedoms spoken about at the time of the celebrations held only a week before. The appeal is subsequently broken up into two separate appeals that will be introduced here chronologically.

First, in the document we read that on September 12, the outcaste village elder S and the other 47 villagers had a meeting with the local officials (including a certain official named $\mathrm{M}$ ) and were informed about the Emancipation Edict. S tells the authorities in the petition that there was 'no greater joy for them' than the Edict. After the meeting that explained the contents of the law, we find that $\mathrm{M}$ had requested that $\mathrm{S}$ and the villagers submit a document saying that they had understood what had been explained to them, providing them with an example of the kind of document he required, adding that 'consideration' should be shown for the surrounding villagers and that (at least temporarily) they should retain their previous status and occupation. S, obviously perturbed by this suggestion, went to another official in the village of the same rank as $M$ presumably to complain, eventually submitting the document on September 22. We find that the local official upheld S's complaint that $\mathrm{M}$ was mistaken for not allowing the Edict to be applied in its entirety effective immediately. By law, S and his village should be referred to as 'former eta' and the local official concluded that M's behaviour was not only illegal but caused problems for the ' 1000 or so farmers' who had no problems with accepting the inclusion of ' 40 or so' outcastes.

But the document continued into another problem, also of great interest. S explains that traditional practices of mortgaging land saw the outcaste's name not written directly onto the document, but rather, the name of a mortgage broker was recorded with a separate document attached that stated that the land was actually being mortgaged by the outcastes themselves. Then, at the time when taxes had to be paid, the taxation notice would first 
record the name of the broker and then secondly the name of the outcaste. The document informs that any rice produced on that land was considered 'outcaste rice' (etamai), and could not be submitted as taxes, but first the outcaste had to exchange his outcaste rice for normal rice and use that to pay taxes which were paid through the mortgage broker. S informs the officials that he had consistently petitioned $\mathrm{M}$ that the eta be allowed to have the land they owned written directly onto the temple registers, something that would legally guarantee their ownership, but until this point $\mathrm{M}$ had flatly refused to comply with such a request. At the end of the document we see $\mathrm{S}$ promising not to sue $\mathrm{M}$, but requesting that the officials allow him (and his villagers) to make a living and to ensure a 'stable life' (anjū) and 'continuity' (sōzoku) for the former eta villagers (MKM,\#16).

This document demonstrates firstly that a national decree that altered the configurations of internal space within the nation did not really ensure that local leaders would be able to re-imagine their local communities in these terms. Although an outcaste had the legal right to be called farmer, there was no assurance that spaces of agricultural production would be made available to them. Even from this document, a sense that the new status of the outcaste, although deeply welcomed by the objects of the Edict who perhaps interpreted it as the creation of egalitarian rural space, was sometimes interpreted in local communities by 'non-outcaste' groups as the homogenisation of space that was acceptable in principle, but would take time to realise. The local community, from which they had been displaced for so long, were often not ready to embrace the return of outcastes to the pure spaces of the peasant, or recognise their inclusion into the rapidly developing notion of 'public space'. The eta, in spite of the legal and legislative changes being made, remained targets of exclusion and alienation - of exile. Certainly, refusal to embrace the 'new ordinary citizens' was blatantly illegal, and dissidents were in danger of severe punitive measures if they persisted with such open and blatant acts of exclusion. Therefore, some members of the local community persisted with the apparatus of internal exile that had been designed in previous times to hold the outcastes in their spaces. These techniques, capably designed, tapped into what were the inherent economic weaknesses that had directly resulted from their lengthy exile. There could be no quantitative or qualitative emancipation without economic emancipation, and the decision by members 
of local communities to continue to exploit old practices that had not been legislated for yet - measures that were essential to help facilitate the rapid repatriation of the exiles back into their new environment - was decisive. The way was made for the return of the outcaste in 1871 , but the absence of concrete measures that protected the economic livelihood of the exile, such as land ownership and revamped systems of taxation, threatened to sweep the recluse exile away in the flood of Japanese modernisation.

Five months later, a New Year - the year of the famous Jinshin koseki or first real modern family register-arrived. Subtle changes in the lives of the new citizens become visible in documents produced in this year. The style of the documents written, for example, reflect these changes. One legal document from Village A (a document submitted annually during the Tokugawa period) dated February 1872 includes the previously unseen statement: 'We no longer exist [as outcastes] and we request compassion [for our current situation]' (MKM,\#9). Other 'former eta' (moto eta) from other villages nearby however, were not enjoying emancipation to the same extent. We come across a draft of a document written by one 'former eta' village headman from Village A that is revised in red ink, presumably by another village outcaste headman. Interestingly, we find that the reason for the production of the document is that the prefectural officials in the lead up to the Jinshin family register refused to offer their seal to documents because 'former eta' in the village, as outcastes, had not had their names included on the previous temple registers of 'ordinary people', and the decision to order their inclusion on the new family registers clearly created bureaucratic headaches for prefectural office officials. It was difficult to make an entire village suddenly and publicly appear out of nothing. Those officiating refused to move on the issue, and the excuse made was that only the prefectural chief, who happened to be away on business, could handle this kind of thing, provoking the former outcaste village headmen to draft a legal appeal against them $(M K M, \# 13)$.

And amidst this tempestuous time of change, we find an extraordinary plea submitted by the former outcaste leader S from Village H. At the beginning of S's petition we find the statement that 'we have already become ordinary citizens,' indicating that the 
Emancipation Edict of the previous year had made a significant impact on him, obviously considering this statement an appropriate building block to instigate a legal appeal. The document goes on to state that the main reason for the appeal lay in the treatment of the village eta Z, who having worked in the village as a mountain guard for several decades, had suddenly been ordered to leave the village by the 'non-outcaste' village official SH. $\mathrm{Z}$ enlisted the help of the villager (and presumably farmer) M who requested on Z's behalf that he be allowed to continue to live in the village for another three years - $\mathrm{a}$ request that was initially granted by $\mathrm{SH}$. However, after a period of time significantly shorter than the three year period, SH suddenly reversed his decision and again demanded that $\mathrm{Z}$ depart from the village declaring that matters of village population registration had become increasingly strict.

$\mathrm{Z}$ then enlisted the help of other former outcaste villagers to appeal to SH on his behalf, including the village headman $\mathrm{S}$ from Village $\mathrm{A}$, but this time to no avail. $\mathrm{Z}$ next procured the help of a local farmer B, who lamented that such a thorny situation had been allowed to evolve, but who could offer no concrete solution on the matter, though still agreeing to participate in the process of negotiation. Eventually, S, M, and Z were all approached by B who became the go-between between the two groups, and in the informal discussion that proceeded were informed that 'the village' believed that $\mathrm{Z}$ had received ample remuneration for the work he had completed in the village over the last few decades, but that 'the village' might possibly consider giving $\mathrm{Z}$ some rice if he promptly left the community. A discussion then ensued between the four men, whereby the figure of 15 ryō of gold was suggested to B as a suitable payment for such a request.

Approximately a week later, a messenger came to Z's hut from $\mathrm{SH}$ suggesting that Z could receive 5 ryo of gold and 5 bags of wheat from the local village lottery fund if he agreed to depart. $\mathrm{Z}$ declined this offer saying that he was in extreme poverty and that he would only move under the condition that he receive 8 ryō of gold and 5 bags of wheat. $\mathrm{SH}$, apparently after consultation with the village, said that he could only offer 4 bags of wheat, whereupon $Z$ broke off negotiations and took up his appeal with the officials. $Z$ concludes his formal statement to the officials by injecting the new information that at the 
time he first moved into the village, he had requested to be allowed to build a dwellinga petition that had been unceremoniously refused. This final appeal to a history of marginalisation showed that there were considerable pent up emotions that $Z$ was experiencing in this process of an initial restoration and subsequent re-exclusion from his community - a community in which he and his ancestors had invested so much time and effort.

Finally, Z, in the latter stages of the document, moved on to different aspects of how the village was making it impossible for him to live in the post-Emancipation Edict era. He relates how another village official called him up, presumably at the time this was all happening, and a document containing the new rules and regulations for the village pertaining to the concrete meaning of the decree were read out to him. In the new rules, we find that $Z$ was ordered to greet everyone at New Year's that he passed by, something he was formerly forbidden to do as an outcaste. We also find that $\mathrm{Z}$ was told that because he was now an 'ordinary citizen,' he would no longer work as a mountain guard, and that he was no longer free to gather sticks and leaves from the main road or mountain paths. $Z$ was also informed that grass to be used as feed for animals could now only be taken from his own property and not communal village land.

Z, predictably, also appealed these new interpretations of the Emancipation Edict to the officials. He informs us that he appealed these regulations because as a mountain guard he had no real land, either for cultivation or for resources, and needed to be able to collect fallen leaves (probably to use or sell as fuel) for his livelihood. He had formally requested permission from the villagers but they had refused both when he had requested personally and when he had made the application through third parties. $Z$ concludes his appeal by stating that not only had his request been denied but that the villagers had conversely counter appealed against him. $\mathrm{Z}$ informs us that he was in extreme poverty and that all his family, both young and old, had 'sunk into despair' and that 'there was no way for them to make a living,' requesting from the authorities a guarantee of his livelihood ( $M K M$, $\# 12)$. 
On March 23, about a month later, we find $\mathrm{Z}$ once again addressing an appeal to the Prefectural Office, this time from a slightly different perspective and providing additional information. Once more, $\mathrm{Z}$ writes at the beginning of the document that he was once an eta, but now a 'general ordinary citizen' (ippan heimin). Z goes on to write that his ancestors had been subordinates (jüboku), working for the village for about 200 years, as mountain guards for a minute allowance. And because $\mathrm{Z}$ was poor, he had no land of his own, but rather worked on a small plot of land near his residence that was non-taxable land because it was infertile. $Z$ writes that last winter, presumably sometime between November and February, the local village official ( $\mathrm{SH}$ ) who owned the land 'north, south, east, and west' of Z's residence informed him that he could no longer work as a mountain guard, and that he would not be able to plant or harvest on his small plot of land (that was formerly exempt from taxation but presumably now taxable land) because he was now an 'ordinary citizen'. He was informed therefore he should move off his land and leave the village. $Z$ tells us that there were 5 people in his family—parents, wife, and child — and that his father was over 70, and his young daughter was blind. $Z$ entreats the officials to have mercy on him and to not let the villagers 'crush him under their feet' (fumitsubushi). We find, we may assume to Z's great relief, at the end of this document that the prefectural officials rule in Z's favour, castigating SH for his misconduct and ordering him to treat $\mathrm{Z}$ as he would everyone else in the village (MKM,\#14). One is left to wonder though the effect such a ruling could have on SH's attitudes to Z.

The plight of $Z$ was indeed an extraordinary one-historically an impure exile, both literally and in the broader senses of the term, living in a hut surrounding by rice paddies owned by the village headman, and working as a guard in the mountains relying on fallen sticks and leaves as well as the meagre salary received from guarding to live. $\mathrm{Z}$ was officially liberated after the promulgation of the Emancipation Edict, and we saw through the previous documents the great joy that this Edict brought to villagers in the neighbouring regions. For many, the Edict was a kind of homecoming, official permission to return to normality and to occupy ordinary spaces - to move out of the 'dangerous spaces' of the mountains and the infertile land that fell between the rice paddies of the village elite, and to reconnect with the fertile spaces of an imagined home, 
environment, and history that had excluded them for (in Z's words) 'the last 200 years.' But some people, like $\mathrm{Z}$, found that through the legal act of emancipation and the official opening up of local spaces, they had actually lost control of the spaces that they had formerly moved in and owned. The community, under the auspices of the village headman, had actually used the act of reconciliation to point out that the ambiguous spaces of the former outcaste were more than ambiguous - they had in fact not really existed at all, that they too were illusions. In a strange twist of logic, the former outcaste became responsible for his future exile from the village by virtue of the fact that he had once been the forced owner of irrational spaces, ones that could not exist in a rational modernity. The act of homogenising space within place that initially promised the end of the exile became the very tool that was used to reinstate a new one.

\section{Conclusion}

It is quite understandable for those displaced — whether they be exile, colonized, or some other ambiguous body - to appropriate the imagery of the outcaste to describe their extraordinary plight. The notion of the exile, as we saw earlier, is a notion deeply touched by the ideas of space and time. The exile is sentenced to live a space apart, and time serves to further compound anxieties related to alienation and loss.

But if the exile may appropriate the imagery of the outcaste, then may the outcaste do the same? We find through pursuing this question that the ideas of internal exile and the outcaste overlap considerably in their spatial dimension-both occupy the same place but different spaces within a collectivity. In the specific example drawn upon in this paper, the onset of modernity altered the structures of space for the $19^{\text {th }}$ century Japanese outcaste in initially a very promising way-falsifying structures of permanence that are normally associated with such a group. Intense waves of spatial homogenisation produced a need to reconstruct national space and constituted a moment akin to a return from exile for the outcaste - they became momentarily the prodigal son. Spatial homogenisation initially suggested a liberation of space and a liberation of structures found in those spaces. And in some ways this was true, particularly for certain sectors of 
the former outcaste leadership. However, in many ways, the rocks and crags that comprised outcaste space — seen as dangerous, impure, and irrational spaces in earlier periods - suddenly became rational, and representative of the frontiers that would need to be conquered for a successful Japanese modernisation. Thus, outcastes were savagely displaced from their familiar landscapes. In addition, the national political movements to create a uniform space were not necessarily accompanied by a nationalisation of space at the local rural level. Urban sites were much quicker at developing policies and systems of homogenisation than were rural areas.

In a very important sense, we may say that the $19^{\text {th }}$ century Japanese outcaste experienced a multidimensional and a repetitive exile-literally excluded from spaces within communal place, displaced through regimes of fear and hate that are inherent in being an outcaste, and re-exiled through the exclusion inherent in modernisation. In the late premodern period, space was configured into communities whereby eta and hinin villages although existing in the same places as non-outcaste villages were dangerous, impure, and powerful places to be avoided at all costs. With the onset of Japanese modernity, these spaces slowly converged into the one space - national space - whereby outcastes had to find their way to the new frontiers, as ordinary citizens, or migrate to new urban slums (McCormack 2002b). Susan Burns has noted too, the disintegration of premodern forms of leper communities in the early Meiji years was quickly followed by the establishment of modern institutions that were designed to clean up after social outcasts that were 'dirtying the streets' (Burns 2003, pp.107-8).

\section{Reference List}

Ambedkar, Bhimrao Ramji 1948, The Untouchables: Who were they and why they became Untouchables, Amrit Book Company, New Delhi.

Anand, Siriyavan 2003, 'Do Brahminical Ideologies Permeate Indian Psychological Theory?', Himal Magazine [Online], 23 April. Available: http://www.countercurrents.org/dalit-anand24403.htm [Accessed 16 May 2004].

Bowman, Glen 1994, "“A Country of Words": Conceiving the Palestinian Nation from the Position of Exile' in The Making of Political Identities, ed. Ernesto Laclau, Verso, London; New York, 138-170.

Burns, Susan L 2003, 'From "Leper Villages" to Leprosaria: Public Health, Nationalism and the Culture of Exclusion in Japan' in Isolation: Places and Practices of 
Exclusion, eds Carolyn Strange and Alison Bashford, Routledge, London; New York, 104-118.

Butler, Judith 2003, 'Afterword: After Loss, What Then?' in Loss: the politics of mourning, eds David L. Eng, David Kazanjian and Judith Butler, University of California Press, Berkeley, 467-473.

Buttimer, Anne 1980, 'Home, Reach, and the Sense of Place' in The Human Experience of Space and Place, eds Anne Buttimer and David Seamon, Croom Helm, London, 166-187.

Chow, Kai-wing, Doak, Kevin M. \& Fu, Poshek 2001, 'Introduction' in Constructing nationhood in modern East Asia, eds Kai-wing Chow, Kevin M. Doak and Poshek $\mathrm{Fu}$, The University of Michigan Press, Ann Arbor, 1-12.

Ha, Marie-Paule April 2001, 'Theme of Exile in Indochinese Return Narratives', Mots Pluriels [Online], no. 17. Available: http://www.arts.uwa.edu.au/MotsPluriels/MP1701mph.html [Accessed May 7 2004].

Harootunian, Harry 2000, Overcome by Modernity: History, Culture, and Community in Interwar Japan, Princeton University Press, Princeton; Oxford.

Hatanaka, Toshiyuki 1999, "Burakushi” no kansei: "buraku mondai wa rekishi ni kiin suru" no ka', Gendai shisō, Vol. 27, no. 2, 52-62.

Imanishi, Hajime 2000, Kokumin kokka to mainoritei, Nihon Keizai Hyōronsha, Tokyo.

Inoue, Kiyoshi 1950, 'Buraku kaihō riron to burakushi no kadai', Sengo buraku mondai ronshū: kaihō riron I, vol. 1, ed. Buraku mondai kenkyūjo hen, Buraku Mondai Kenkyūjo, Kyoto, 76-85.

1963, Nihon no rekishi (jō), vol. 1, Iwanami Shinsho, Tokyo.

Kobayashi, Shigeru 1988, Hisabetsu buraku no rekishi, Akashi Shoten, Tokyo.

Lie, John 2001, 'Narratives of exile and the search for homeland in contemporary Japanese Korean writings' in Constructing Nationhood in Modern East Asia, eds. Kai-wing Chow, Kevin M. Doak and Poshek Fu, The University of Michigan Press, Ann Arbor, 343-358.

M-kemonjo, Saitama Prefectural Archives, Urawa.

McCormack, Noah 2002a, 'Buraku Emigration in the Meiji Era: Other Ways to Become Japanese', East Asian History, no. 23, 87-108.

2002b, 'Making Modern Urban Order: Towards Popular Mobilisation', Japanese Studies, vol. 22, no. 3, 257-272.

Memmi, Albert 1965, The Colonizer and the Colonized, The Orion Press, New York. Minegishi, Kentarō 1996, Kinsei hisabetsuminshi no kenkyū: Azekura Shobō, Tokyo. Morris, Dana, \& Smith, Thomas C. 1985, 'Fertility and Mortality in an Outcaste Village in Japan, 1750-1869' in Family and Population in East Asian History, eds. Susan B. Hanley and Arthur P. Wolf, Stanford University Press, Stanford, 229-246.

Morris-Suzuki, Tessa 1996, 'The Frontiers of Japanese Identity' in Asian Forms of the Nation, ed. Stein Tonnesson and Heins Antlove, Curzon, Richmond, 41-66. 2000, 'Roads to Otherness: Ainu and Identity Politics in Twentieth-Century Japan' in Japanese Studies: Communities, Cultures, Critiques, eds. V. Mackie, A, Skoutarides and A.Tokita, Monash Asia Institute, Clayton, 35-59.

Mukerji, Dhan Gopal 1925, Caste and Outcast, E.P. Dutton, New York. 
Naficy, Hamid 1999, 'Introduction: Framing Exile' in Home, Exile, Homeland: Film, Media, and the Politics of Place, ed. Hamid Naficy, Routledge, New York; London, 1-13.

Osatake, Takeki 1999, Meiji yonnen senshō haishi fukoku no kenkyū, Hihyōsha, Tokyo. Hirota, Masaki 1990, Sabetsu no shosō, vol. 22 in Nihon kindai shisō taika, ed. Shüichi Katō, Iwanami Shoten, Tokyo.

Said, Edward W. 1994, Representations of the Intellectual: the 1993 Reith Lectures, Pantheon Books, New York.

Seshimo, Hirohito 1982, 'Kinsei hisabetsu buraku no shichi deiri' in Kantō / tōkai hisabetsu burakushi kenkyū, ed. Kōjirō Arai, Akashi Shoten, Tokyo, 265-304.

Suh, Kyungsik. What it means to be a 'quasi-refugee', Japan Focus, Available: http://japanfocus.org/080.html [Accessed May 6 2004].

Suzukikemonjo, Saitama Prefectural Archives, Urawa.

Tsukada, Takashi 2000, Mibunron kara rekishigaku wo kangaeru, Azekura Shobō, Tokyo.

Wakita, Osamu 1987, 'Kinsei mibunsei to buraku no seiritsu' in Burakushi no kenkyū, ed. Buraku Mondai Kenkyūjo Hen, Buraku Mondai Kenkyūjo, Kyoto, 127-148.

Walthall, Anne 1986, Social Protest and Popular Culture in Eighteenth-Century Japan, The University of Arizona Press, Tucson.

Yuval-Davis, Nira 2003, 'Human Security' and the Gendered Politics of Belonging', Proceedings of Justice, Equality and Dependency in the "Postsocialist" Condition, Centre for the Study of Women and Gender, The University of Warwick, Available:

http://www2.warwick.ac.uk/fac/soc/sociology/gender/events/symposium/yuval/ [Accessed May 15 2004].

7 Nov. 2002, 'Reformist scholar sentenced to death in Iran', Associated Press Newswires [Online]. Available: Factiva [Accessed May 10 2004]. 